\title{
Family farming in agroecological transition: a look at the marketing of milk and dairy products in municipalities of the Zona da Mata of Minas Gerais State, Brazil
}

\author{
Priscila Alves dos Santos $^{1}$ (i) Paula Dias Bevilacqua ${ }^{2 *}$ (i)
}

${ }^{1}$ Programa de Pós-Graduação em Medicina Veterinária, Universidade Federal de Viçosa (UFV), Viçosa, MG, Brasil.

${ }^{2}$ Departamento de Veterinária, Programa de Pós-Graduação em Medicina Veterinária, Universidade Federal de Viçosa (UFV), 36.570-900, Viçosa, MG, Brasil. E-mail: paula@ufv.br. "Corresponding author.

ABSTRACT: This study evaluated the limits and possibilities of the marketing of milk and dairy products in the context of family farming. We used semi-structured interviews, document analysis, and content analysis as methodological options. We conducted 12 interviews with family farmers who had milk production and the processing and marketing of this raw material in common. Despite changes and reformulations, federal and state legislation still does not consider small family farmers. Even when referring to these protagonists, the legislation address production in a technical manner that is inadequate for the reality of most family farmers, thus favouring dairy industries.

Key words: dairy cattle production, dairy products, public policies, family agroindustry.

Agricultura familiar em transição agroecológica: um olhar sobre a comercialização de leite e derivados em municípios da Zona da Mata de Minas Gerais

RESUMO: Objetivou-se avaliar os limites e possibilidades da comercialização de leite e seus derivados no contexto da agricultura familiar. Utilizamos entrevistas semiestruturadas, análise documental e análise de conteúdo como opções teórico-metodológicas. Realizamos 12 entrevistas com agricultores familiares que tinham em comum a produção leiteira e o processamento e a comercialização dessa matéria prima. Apesar de mudanças e reformulações, as legislações federais e estaduais ainda não contemplam os pequenos agricultores familiares. Mesmo que em alguns casos remetam a esses protagonistas, as legislações nitidamente discursam sobre uma prática tecnificada de produção, inadequada à realidade da maioria dos agricultores, favorecendo, assim, às indústrias laticinistas.

Palavras-chave: produção bovina de leite e derivados, politicas públicas, agroindústria familiar.

\section{INTRODUCTION}

Family farms represent $84 \%$ of rural enterprises, accounting for $38 \%$ of the gross value of national agricultural production. Milk production is one of the main activities, taking place in $36 \%$ of rural enterprises. In 2006, 223,073 rural enterprises produced milk in Minas Gerais State, of which $75 \%$ were family farms (IBGE, 2010).

Despite the significant participation of these enterprises in the national economy, it was only in the mid-1990s that family farming became part of the public policy agenda of rural development, with the publication of an emblematic political action, the National School Feeding Programme (PNAE). Although this program has encouraged the participation of family farmers in the supply of products for school feeding, access to the government market requires technical adjustments that often impose severe restrictions on the specific characteristics of certain products, such as those from family farming. In an exploratory study, COSTA et al. (2015) reported that sanitary adequacy of products is one of the most important requirements for family farms to access these markets.

Studies conducted by the Extension Group Associated with Research and Teaching 'Animals for Agroecology' showed a growing interest of family farmers in agroecological transition to market milk and dairy products produced on their properties. We define agroecological transition as a gradual process of transformation from a 'conventional' productive model, based on the use of pesticides and dependence on external inputs, to a production system that has its resources, aiming the autonomy of the farming family (CAPORAL \& COSTABEBER, 2002). For authors such as Caporal and Altieri, agroecology is more than a production technique, it is a paradigm shift, 
in which scientific knowledge from different fields approximate to traditional (or farmer) knowledge to criticize and overcome the capitalist mode of production, materialized in rural areas in the form of industrial agriculture. Thus, complex agricultural systems are valued, with several elements (plants and animals) and microenvironments maintaining cycles of materials and waste and providing soil fertility, productivity, and crop protection (ALTIERI, 2004; CAPORAL et al., 2011).

In this perspective, agroecological production implies social and cultural changes that impact the environmental dimensions and quality of products produced. Thus, it is not only a mode of production that seeks to produce food that poses less risk to the health of consumers (such as production free of pesticides), or that causes less environmental impact, which undoubtedly adds value (including economic value) to products.

With the valuation of agroecological products, farmers now realise the need to formalize and regulate their production to meet local demands and/or even market their products to nearby municipalities. However, several issues may pose difficulties to make this process feasible. In this sense, we aimed to analyse the limits and possibilities of marketing products of animal origin (milk and dairy products) by family farmers in agroecological transition by discussing the existing legal determinations, at the national and state levels (Minas Gerais).

\section{MATERIAL AND METHODS}

This study was conducted in twelve properties of family farms from three municipalities (Divino, Viçosa and Muriaé) in the Zona da Mata mesoregion, Minas Gerais State, between November 2015 and September 2016. The following criteria were used to choose the participants: (i) being a family farmer in agroecological transition; (ii) producing milk; (iii) producing (or not) milk products (cheese, butter, curd, yoghurt or sweets) and (iv) marketing these products (milk and/or milk products).

The methodological options chosen for data collection were semi-structured interviews and documentary analysis. The interviews were individual, recorded with a digital recorder, and conducted at the home of the participants so that the meeting could be conducted in an easy-going manner with an informal, prose-like tone or a chat. The semi-structured interview provides an open dialogue, allowing the participants to express their thoughts and opinions without the limitations posed by a closed questionnaire (TRIVIÑOS, 1987). Interviews were transcribed, maintaining the fidelity of narratives. It should be noted that transcription is not only the writing of narratives but also a moment for pre-analysis and interpretation of the collected data (HAGUETTE, 2010). To complement and enrich the interview data, we used a field notebook to record the participants' comments and narratives before and/ or after using the recorder. A field notebook is an important tool used in qualitative research, allowing the detailed recording of information, observations, and reflections that emerge in the development of the research and that will later be used by the researcher in the analysis of the collected data (AZEVEDO\& CARVALHO, 2009; HAGUETTE, 2010).

Documentary analysis was performed through a bibliographic survey on federal and state public policies that define and organise the marketing of milk and milk products. This survey followed the chronological order of the documents (from 1950 to 2018), seeking to build a historical reference of this legal framework.

The systematization and treatment of data followed content analysis assumptions, a technique that seeks to understand and critically analyse the meaning of the objects of study, whether narratives or documents (TRIVIÑOS, 1987; BARDIN, 2011). Legal documents were analysed by their in-depth reading and the identification of the changes that occurred, mainly related to the requirements for marketing, whether from the technical point of view and/or organization of the production and processing. The narratives of the semi-structured interviews were organized into three categories of analysis: (i) cost of compliance with legal requirements; (ii) product quality and food safety; and (iii) marketing strategies.

\section{RESULTS}

The subject 'marketing of products of animal origin' is associated with the inspection of these products and, in Brazil, the first legal document published that addresses it, is the Federal Law No. $1.283 / 1950$, regulated by Decree No. 30.691/1952, which requires the previous industrial and sanitary inspection of all products of animal origin (BRASIL, 1950). Considering milk and milk products, both legislations refer to industrial and large-scale production, as expressed in the definitions of the enterprises subject to inspection: dairy farms and dairy stables. In any case, they refer to production for 'industrial purposes' (dairy farm) or to the type of product (type B or type A milk, dairy stables and 
dairy farms, respectively) (BRASIL, 1950; BRASIL, 1952), whose production depends on more specialised techniques and technologies.

In 2017, Decree No. 9.013 revoked the decree of 1952 , and changed the classification of enterprises subject to inspection to dairy farm, refrigeration station, processing plant, dairy and cheese factory (BRASIL, 2017). However, the definition of dairy-producing enterprises (dairy farms) continued, encompassing the meaning of sites with characteristics of industrial production.

Law No. 1.283/1950 defined the Ministry of Agriculture and the state agriculture secretariats as the entities responsible for the inspection of products of animal origin in enterprises, which produce, benefit or store products, including warehouses. In 1989, Law No. 7.889 extended the responsibility to the secretariats or departments of agriculture of the municipalities. Thus, each sphere of the executive power had specific competencies related to the places/types of marketing and issued the respective stamps of the inspection service (federal, state or municipal) (BRASIL, 1950; BRASIL, 1989). Law No. 8.171/1991 defined the agricultural policy in Brazil, highlighting the diversity of enterprise included in the agricultural production context. Agricultural production was defined as what "occurs in rural enterprises that are heterogeneous in terms of land structure, soil and climate onditions, availability of infrastructure, business capacity, technological levels, and social, economic and cultural conditions" (BRASIL, 1991). Once this assumption was established as a fundamental principle, it would influence subsequent legislation.

The Unified Agricultural and Livestock Health System (SUASA) (Law No. 8.171/1991 and Decree No. 5.741/2006) innovatively proposed the integration between monitoring and inspection of agricultural and livestock products and the promotion of human health, making explicit the necessary articulation with the Unified Health System. Accordingly, the scope of actions was broadened, indicating that the principles and obligations applied to all phases of "production, transformation, distribution, and agricultural services". The "rural producers and other members of the production chains" are also actors in the co-operation process to ensure actions and improve agricultural and livestock health (BRASIL, 2006). However, it was only in 2010, with Decree No. 7.216, which established that SUASA had to respect "the regional specificities of products and different scales of production, including small agro-industrial enterprises" (BRASIL, 2010), that family farming appeared as a space for the production of products of animal origin.

In Minas Gerais State, Law No. 19.476 of 2011, regulated by Decree No. 45.821 of 2011, established rules for qualification (register, and sanitary certificate), facilities, equipment, product quality control, educational activities and marketing of products by small agro-industrial enterprises. In line with these documents, the Minas Gerais Agricultural Institute (IMA), the agency responsible for inspection in the state, published Ordinance No. 1.252 in 2012 which approved the technical standards for small rural enterprises producing products of animal origin. That is, only after Decree No. 7.216/2010 and other legal documents specific to Minas Gerais State, family farming properties were considered as places of production of products of animal origin in this state.

Despite the State's initiative in supporting the inclusion of familiar farmers to the processes of agro-industrialisation, the demands, such as those referring to the physical structure and equipment, until today make unfeasible the implementation of agroindustries in small rural properties and the adaptation of the production to norms and procedures.

Most participants in this research mentioned this aspect. They reported that the investment was high and that the return might be inadequate due to the small number of animals and raw material produced per day (which ranged from five to 60 litres on the properties). Some interviewees mentioned obtaining financing to invest in infrastructure (facilities and equipment) but were unable to pay for it. Among the twelve families interviewed, only one, from the municipality of Viçosa, could adapt to the current legislation. It is worth mentioning that the income of this family was not only derived from work on the property, but also from paid activities in the urban area, which was invested in the improvement of the property's infrastructure.

Laws mentioned above classify establishments by infrastructure, disregarding the volume/scale of production. Thus, farmers who process a small volume of raw material per day are unable to invest or assume risks when investing in physical structure/equipment, since there is great uncertainty about the financial return and the consequent continuity of production.

Decree No. 9.013/2017 stated that small agro-industrial enterprises producing products of animal origin had to follow specific complementary rules related to infrastructure and equipment (BRASIL, 2017). MAPA Normative Instruction No. 
5 (IN MAPA No. 5/2017) was sanctioned in the same year. Contrary to previous legislation, which classified enterprises by infrastructure, IN MAPA No. 5/2017 defines small agro-industrial enterprises for milk and dairy products based on the maximum volume of milk processed on the property, established as 2,000 litres of milk per day (MAPA, 2017). This recent change may mean progress for family production, and its impacts still need to be measured and evaluated.

The participants in this research also questioned the method of manufacture in large dairy companies. Farmers claimed that their workplaces and processing practices were more appropriate because, in addition to the smaller volume of milk processed, they were more careful with health in general and the handling of raw materials. Moreover, they stated that the production carried out by the same person would ensure better quality and no adulteration of the products, since it avoided the turnover of those who handled the raw material and performed the other procedures.

Among the forms of marketing of milk and/or dairy products, the following were reported: direct sale to the consumer, door-to-door or through orders; sale in open markets or small local markets and/or sale of milk to dairy companies. According to reports, sales on local markets, a widespread practice in the past, were no longer practiced, due to the fear that the inspection bodies would punish the owners of these stores. Thus, when this research was conducted, the main strategy for marketing products was the direct sale to consumers, which encouraged them to maintain dairy activities. The sale of milk to the dairy industry was an option for some farmers, but not the most desired option because it did not allow the production of dairy products and the possible profit from the sale of these products.

In 2018, Federal Law No. 13.680 was published, amending Law No. 1.283/1950, authorising the "interstate marketing of artisanal food products with their own traditional or regional characteristics and methods of production and the employment of good agricultural and manufacturing practices, provided they are submitted to inspection by public health agencies of the States and the Federal District". This law also created the label ARTE (ART) for the identification of the artisanal product (BRASIL, 2018).

Nevertheless, according to Law No. $13.680 / 2018$, the requirements for the registration of the establishment and the product should be adequate to the dimensions and purposes of the enterprise, and the registration procedures should be simplified. Another aspect that updates the traditional conduct of inspection of products of animal origin (artisanal products) is the recommendation that these activities should have "primarily guiding character" (BRASIL, 2018).

\section{DISCUSSION}

Legislation dealing with the marketing of animal products is undoubtedly strict, especially regarding the technical aspects related to infrastructure (facilities and equipment). Requirements for dairyproducing enterprises are higher since dairy products are in many cases produced in the same enterprise that produces the raw material, milk. Thus, they should comply with legislation regarding the production of the raw material and the dairy products.

Until the beginning of the 2000s, the legislation on this subject did not make explicit reference to family farming, completely disregarding this place of production. Although the preservation of human health was the focus of the requirements imposed by legislation, the scope of the legal documents disregards family production, because family farmers would have to heavily invest in infrastructure to comply with legal requirements. Moreover, according to PREZOTTO (2002), even if the adjustments were made, the small scale of production, characteristic of family farming, would not be enough to return the invested capital, compromising the viability of the productive process.

In the definitions that appear in the legal documents that outline their respective fields of action, industrial production is mentioned as the privileged mode of production. Thus, two forms of production are described, one supported by technical guidelines and procedures and legitimized by legal ordinances and the other characterized by artisan and family production. The latter, having its own procedures, departs from the technical recommendations arising from technical-scientific knowledge and thus have no legal support.

To expand the scope of action of the inspection of enterprises producing products of animal origin, the municipality was included as responsible for these activities (Law No. 7.889/1989). For SANTANA \& FAGNANI (2014), this expansion was, on the one hand, positive because it brought the responsible agencies closer to the enterprises where the products were manufactured, a fact that provided an understanding of the reality of the locations and their forms of production, thus facilitating the registration process. However, conversely, it has imposed geographical limitations on marketing. 
The opportunity to get in touch with the reality of milk and dairy products production in family farms may have provided the inspection body with knowledge of the heterogeneity of this production. However, the legal requirements remained the same, not matching such realities and supporting exclusion of these products from the formal market. According to CENCI (2007) and COSTA et al. (2015), legislation on the inspection and marketing of milk and dairy products continues to be developed with a focus on large industries, making it difficult for small farmers to enter the formal market and making production illegal and unsuitable for human consumption, because without the required infrastructure, products cannot be certified and do not receive inspection authorizing their marketing. Even recent legislation, such as Law No. 13.680/2018, which suggests that registration procedures for enterprises and products of animal origin should be flexible and that the inspection should be conducted in a guiding manner, fail to bring significant changes for family farming. This is because despite this law, all procedures related to the marketing of products, including registration of the production facility and the product, and classification, control, and inspection of the product should still follow the Law No. 1.283/1950 and its regulation, in this case, Decree No. 9.013/2017, known as being restrictive and detailed. Law No. $13.680 / 2018$ aimed to allow interstate marketing of artisanal products, provided they meet requirements related to registration (production facility and product), facilities and equipment, hygiene conditions, industrial and sanitary inspection, identity and quality standards (among others), which does not necessarily favour local family production.

For PREZOTTO (2002), analysing this small-scale production environment and finding methods and forms of 'miniaturization' of facilities and equipment is necessary so that they can be implemented individually in family properties. LIMA (2014), in turn, questions if 'miniaturization' proposed by PREZOTTO (2002) is even a valid and important strategy to adapt to laws, stating that this view imposes on farmers a form of production similar to the industrial model, denying their traditional and regional practices. According to LIMA (2014), the sanitary requirements imposed by legislation comprises a subtle discourse that states that only the industrial way of processing food provides food security for consumers.

Farmers' reports contradicted this discourse. They stated that the traditional way of producing and processing milk and dairy products and the small volume of production reduces the chances of contamination and adulteration of products compared to the industrial model. SCHNEIDER et al. (2013) stated that disregarding traditional and cultural aspects and focusing on the risks to the food security of consumers can lead to the extinction of popular and traditional knowledge and discouraging this type of production. In the context of this study, considering family farmers in agroecological transition, the perspective of agroecology enables a holistic and integrated view of production, seeking economic gain and environmental preservation, health promotion, and valuation and preservation of traditional techniques of production, constituting a conscious and explicit resistance to industrial models.

For BUAINAIN \& SOUZA FILHO (2006), in addition to the aspects explained, farmers who choose this type of production take advantage of the expansion of markets due to the awareness of consumers, who are concerned about environmental issues and; consequently, seek healthier food. Thus, they add value to their products and increase family income.

Experiences of agroecological production and marketing of these products have shown their effectiveness in the case of products of vegetable origin (fruits and vegetables) and processed foods (coffee, baked goods). These products have important characteristics such as being of better quality, pesticide-free, and having fairer prices (SILVA \& AMORIM JÚNIOR, 2013; COSTA et al., 2015), besides the political bias of strengthening family farming. However, the effort to establish a space of resistance to the industrial model of production is impaired by several requirements and obstacles for the sanitary certification of products of animal origin. This limits marketing options either to formality, such as the sale of milk to dairy industries (making the farmers dependent on the prices imposed, which do not match the costs of production) or informality, such as direct sale to consumers, possibly causing the exclusion of traditional forms of marketing, such as fairs and local markets, according to the reports of farmers in this study.

PLOEG (2008) indicated the need for a new style of rural development, in which farmers have ties with different markets, different from the current ties, characterized by dependence, low prices and no autonomy of the farmer. According to WEZEL et al. (2009), agroecology and its organizations/social movements would be a path for (re)inventing and overcoming dependence on large industries and this type of food market. 
SCHNEIDER et al. (2013) stated that the permanence of family farmers in a marginalized and vulnerable situation impairs direct sales to consumers, making it impossible to expand production and; consequently, marketing. Conversely, it created a way to add value to products and enables them to continue their professional activity. WILKINSON (2008) called local markets proximity markets, because, mostly, there are kinship or proximity ties (friendship), and this type of relationship is fundamental for the sale of milk and dairy products in the market. Even though it is an illegal form of marketing, it is still practiced in places where the inspection systems are flawed (SCHNEIDER et al., 2013).

\section{CONCLUSION}

Despite advances, such as the consideration of small production and the respect for its specificities, laws still maintain the industrial character that does not fit the reality of family farming. Therefore, they are still thought, drafted and sanctioned to favour dairy industries.

Although legal texts include these protagonists (family farmers) and ensure the legitimacy of the products produced, the legislation is not implemented rationally or immediately, but also requires, or primarily requires, the definition of public policies that contemplate broader aspects than the simple technical conformity of production and/or products.

\section{ACKNOWLEDGEMENTS}

The authors thank the family farmers who kindly participated in the study. We thank the Centro de Tecnologias Alternativas da Zona da Mata (CTA-ZM) for the support during the development of the study. Finally, we thank the Fundação de Amparo à Pesquisa do Estado de Minas Gerais (FAPEMIG) (Processo CVZ-APQ-03205-14) and PROEXT/MEC/SESu for their financial support to research and scholarships. P.A. dos Santos was funded by a FAPEMIG research fellowship.

\section{ETHICS COMMITTEE}

The research protocol was submitted to and approved by the Ethics Committee on Research with Human Beings of the Universidade Federal de Viçosa (Protocol No. 1.587.011).

\section{DECLARATION OF CONFLICT OF} INTERESTS

The authors declare no conflict of interest. The founding sponsors had no role in the design of the study; in the collection, analyses, or interpretation of data; in the writing of the manuscript, and in the decision to publish the results.

\section{AUTHORS' CONTRIBUTIONS}

PAS e PDB conceived and designed the study; and participated in analysis and interpretation of data. PAS conducted data collection and systematization. Both authors contributed equally for the conception and writing of the manuscript, and critically revised the manuscript and approved final version.

\section{REFERENCES}

ALTIERI, M. Agroecologia: a dinâmica produtiva da agricultura sustentável. Porto Alegre: Editora da UFRGS, 2004. $120 \mathrm{p}$.

AZEVEDO, B.M.S.; CARVALHO, S.R. O diário de campo como ferramenta e dispositivo para o ensino, a gestão e a pesquisa. In: CARVALHO, S.R. et al. Conexões: saúde coletiva e políticas da subjetividade. São Paulo: Hucitec, 2009. Cap.11, p. 204-219.

BARDIN, L. Análise de conteúdo. São Paulo: Edições 70, 2011. 280p.

BRASIL. Decreto ${ }^{\circ} 5.741$, de 30 de março de 2006. Regulamenta arts. 27-A, 28-A e 29-A, Lei $\mathbf{n}^{0}$ 8.171, 17 de janeiro de 1991, organiza Sistema Unificado de Atenção à Sanidade Agropecuária. Diário Oficial da União, Brasília, DF. Available from: $<$ http://portal. imprensanacional.gov.br>. Accessed: Mar. 12, 2018.

BRASIL. Decreto $\mathrm{n}^{\circ}$ 7.216, de 17 de junho de 2010. Aprova, dá nova redação e acresce dispositivos ao Regulamento dos arts. 27-A, 28-A e 29-A, Lei no 8.171, de 17 de janeiro de 1991, aprovado pelo Decreto $\mathrm{n}^{\circ} \mathbf{5 . 7 4 1}$, de 30 de março de 2006. Diário Oficial da União, Brasília, DF. Available from: $<$ http://www. planalto.gov.br>. Accessed: Mar. 12, 2018.

BRASIL. Decreto $\mathrm{n}^{\circ}$ 9.013, de 29 de março de 2017. Regulamenta Lei $\mathrm{n}^{\circ} 1.283,18$ de dezembro de 1950, Lei $\mathbf{n}^{\circ}$ $7.889,23$ de novembro de 1989, que dispõem sobre a inspeção industrial e sanitária de produtos de origem animal. Diário Oficial da União, Brasília, DF. Available from: $<$ http://www. planalto.gov.br/ccivil_03/_ato2015-2018/2017/decreto/d9013. htm>. Accessed: Mar. $12, \overline{2} 018$.

BRASIL. Decreto n ${ }^{0} 30.691$, de 29 de março de 1952. Aprova o novo Regulamento da Inspeção Industrial e Sanitária de Produtos de Origem Animal. Diário Oficial da União, Brasília, DF. Available from:<http://www.planalto.gov.br/ccivil_03/ decreto/1950-1969/d30691.htm>. Accessed: Mar. 12, 2018.

BRASIL. Lei Federal $\mathrm{n}^{\circ} 1.283$, de 18 de dezembro de 1950. Dispõe sobre a inspeção industrial e sanitária de produtos de origem animal. Diário Oficial da União, Brasília, DF. Available from: $<$ http://www.planalto.gov.br/ccivil_03/leis/L1283.htm>. Accessed: Mar. 12, 2018.

BRASIL. Lei Federal n 7.889 , de 23 de novembro de 1989. Dispõe sobre a inspeção sanitária e industrial de produtos de origem animal. Diário Oficial da União, Brasília, DF. Available from: <http://www.planalto.gov.br/ccivil_03/leis/17889.htm>. Accessed: Mar. 12, 2018.

BRASIL. Lei Federal n ${ }^{\circ} 8.171$, de 17 de janeiro de 1991. Dispõe sobre a política agrícola. Diário Oficial da União, Brasília, DF. Available from: $<$ http://www.planalto.gov.br/ccivil_03/Leis/ L8171.htm>. Accessed: Mar. 12, 2018. 
BRASIL. Lei Federal no 13.680 , de 14 de junho de 2018. Altera a Lei $\mathrm{n}^{\circ} \mathbf{1 . 2 8 3}$, de 18 de dezembro de 1950, para dispor sobre o processo de fiscalização de produtos alimentícios de origem animal produzidos de forma artesanal. Diário Oficial da União, Brasília, DF. Available from: <http://www.planalto.gov.br/ ccivil_03/_Ato2015-2018/2018/Lei/L13680.htm>. Accessed: Jan. 10,2019 .

BUAINAIN, A.M.; SOUZA FILHO, H.M. Agricultura familiar, agroecologica e desenvolvimento sustentável: questões para debate. Brasília: Instituto Interamericano de Cooperação para a Agricultura, 2006. 136p.

CAPORAL, F.R.; COSTABEBER, J.A. Agroecologia. Enfoque científico e estratégico. Revista Agroecologia e Desenvolvimento Rural Sustentável, v.3, n.2, p. 13-16, 2002. Available from:<www. pvnocampo.com.br/agroecologia/agroecologia.pdf $>$. Accessed: Mar. 25, 2018

CAPORAL, F.R.; COSTABEBER, J.A.; PAULUS, G. Agroecologia: matriz disciplinar ou novo paradigma para o desenvolvimento rural sustentável. In: CAPORAL, F.R.; AZEVEDO, E.O. Princípios e perspectivas da agroecologia. Paraná: Instituto Federal de Educação, Ciência e Tecnologia, 2011. Cap.2, p.45-82.

CENCI, A. Análise do perfil das agroindústrias familiares situadas na Região do CONDESUS. 2007. 139f. Dissertação (Mestrado em Extensão Rural e Desenvolvimento) - Curso de Pósgraduação em Extensão Rural, Universidade Federal de Santa Maria.

COSTA, B.A.L. et al. As cooperativas de agricultura familiar e o mercado de compras governamentais em Minas Gerais. RESR, v.53, n.1, p.109-126, 2015. Available from: $<$ www.scielo.br/pdf/ resr/v53n1/0103-2003-resr-53-01-00109.pdf $>$. Accessed: Mar. 26 2018. doi: 10.1590/1234-56781806-9479005301006.

HAGUETTE, T.M.F. Metodologias qualitativas na sociologia. Petrópolis: Vozes, 2010. 112p.

IBGE - INSTITUTO BRASILEIRO DE GEOGRAFIA E ESTATÍSTICA. Censo Demográfico-2006-Agricultura familiar no Brasil e Censo Agropecuário. BRASIL, 2010.

LIMA, R.S. Queijo minas artesanal: impasses e trajetórias vivenciadas pelos produtores rurais para manter uma cultura tradicional. In: REUNIÃO BRASILEIRA DE ANTROPOLOGIA, 29 ${ }^{\circ}$ 2014, Natal, RN. Anais... Natal: UNIOESTE, 2014. p.598-611.

MAPA - MINISTÉRIO DA AGRICULTURA, PECUÁRIA E ABASTECIMENTO Instrução Normativa $\mathrm{n}^{\circ}$ 5, de 14 de fevereiro de 2017. Dispõe sobre requisitos para avaliação de equivalência ao Sistema Unificado de Atenção à Sanidade Agropecuária relativos à estrutura física, dependências e equipamentos de estabelecimento agroindustrial de pequeno porte de produtos de origem animal. Diário Oficial da União, Brasília, DF. Available from: <www.leigeral.com.br/files/ exportFromView/4545>. Accessed: Jan. 10, 2019.

PLOEG, J.D.V.D. Camponeses e impérios alimentares: lutas por autonomia e sustentabilidade na era da globalização. Rio Grande do Sul: UFRGS, 2008. 372p.

PREZOTTO, L.L. Uma concepção de agroindústria rural de pequeno porte. Revista de Ciências Humanas, v. 31, n.1, p.133154, 2002. Available from: $<$ https://periodicos.ufsc.br/index.php/ revistacfh/article/download/25195/22152>. Accessed: Mar. 26, 2018. doi: $10.5007 / \% 25 x$.

SANTANA, E.H.W.; FAGNANI, R. Legislação brasileira de leite e derivados. Londrina: Unopar, 2014. 298p.

SCHNEIDER, S. et al. O perfil da agroindústria aural no Brasil: uma análise com base nos dados do censo agropecuário 2006. Brasília: Instituto de Pesquisa Econômica Aplicada. 2013. 83p.

SILVA, M.G; AMORIM JÚNIOR, P.C.G. Inovações organizacionais para a construção de mercados locais e solidários em Espera Feliz (MG). Agriculturas, v.10, n.2, p.14-17, 2013. Available from:<aspta. org.br/wp-content/uploads/2013/09/Revista-Agriculturas-V10N2Artigo-2.pdf $>$. Accessed: Mar. 26, 2018.

TRIVIÑOS, A.N.S. Introdução à pesquisa em ciências sociais: a pesquisa qualitativa em educação. São Paulo: Atlas, 1987. 175p. WEZEL, S. et al. Agroecology as a science, a movement and a practice. A review. Agronomy for Sustainable Development, v.29, n.4, p.503-516, 2009. Available from: $<$ https://www. agronomy-journal.org > . Accessed: Mar. 25, 2018. doi: 10.1051/ agro/2009004.

WILKINSON, J. O Estado, a agricultura e a pequena produção. Rio de Janeiro: Centro Edelstein, 2008. 229p. 